\title{
Covid-19: benefit for death in service may not go far enough, warns BMA
}

\section{Abi Rimmer}

The BMJ

Families of NHS workers who die from coronavirus in the course of their work will receive a $£ 60000$ ( $€ 69000$; \$75 000) payment, the government has announced.

The BMA has warned, however, that while the sum may provide some immediate financial relief it could leave families bereft of longer term financial security.

The association said that this was particularly the case for staff who were not current members of the NHS pension scheme or who had only recently joined the scheme.

Before the announcement, only members of the NHS pension scheme were eligible for death in service benefits. The BMA also warned that locum doctors would not be eligible for benefits if they died on a day that they are not scheduled to work. ${ }^{1}$

The government has said that its new scheme-which will award a $£ 60000$ lump sum to bereaved families-will cover full time, part time, and locum NHS and public health workers. This includes GPs, dentists, retired staff, and second and final year students taking up paid frontline roles in England. ${ }^{2}$

The BMA said that without the full details of the scheme, however, it was not reassured that it would go far enough to assist families.

Vishal Sharma, BMA Pensions Committee chair, said, "While this single payment may seem a sizeable sum, it comes nowhere near compensating families for the lifetime income their loved one may have earned if they hadn't died prematurely, fighting this crisis on the frontline. This is particularly true for young or recently qualified staff.

"Increasing numbers of families are dealing with the loss of a loved one as the death toll for front line workers rises, they should not also face a future without financial security. The BMA will be examining closely the detail of the government's life assurance scheme."

The scheme is time limited and will provide cover for the duration of the pandemic, the government has said. Eligibility is work related and it will cover those who die from coronavirus during their work. This includes those providing direct care as well as cleaners and porters.
Employers will be asked to initiate claims on behalf of families and claims will be verified and processed by the NHS Business Services Authority, who will work with employers to ensure claims are handled swiftly and sensitively.

While the recent announcement covers NHS workers in England, Wales is also implementing the same scheme and arrangements are being considered in Scotland and Northern Ireland, the government said.

\section{Death in service benefits}

If a doctor who is a member of the NHS pensions scheme dies in service a lump sum is payable.

For most doctors who are active members of the NHS pension scheme, the value of this lump sum will be around two times their annual pensionable pay, depending on which pension scheme they are a member of. ${ }^{4}$

For doctors who are retired but have returned to work the value of this lump sum is likely to either be five times their pension, minus any pension already paid, or twice their pay minus any retirement lump sum already paid, depending on which scheme they are a member of

If the doctor has a spouse or civil partner, a qualifying partner, or eligible children, dependants' benefits will also be payable.

For doctors who are active members of the pension scheme and have at least two years' membership, the benefits payable to a spouse or partner will be between $33.75 \%$ and $50 \%$ of their pension, plus an additional pension payment for three months, depending on which pension scheme they are a member of.

Doctors with less than two years membership of the scheme are not eligible for this benefit.

Rimmer A. Covid-19: BMA demands full death in service benefits for UK doctors. BMJ 2020;369:m1634. 10.1136/bmj.m1634 32327407

2 Department of Health and Social Care. New guarantee on death in service benefits for frontline health and care staff during pandemic. 27 April 2020. www.gov.uk/government/ news/new-guarantee-on-death-in-service-benefits-for-frontline-health-and-care-staffduring-pandemic.

3 BMA. Death in service and your pension. 31 March 2020. www.bma.org.uk/pay-andcontracts/pensions/in-the-event-of-death/death-in-service-and-your-pension.

4 NHS Employers. NHS pension scheme: life assurance and family benefits. April 2020 www.nhsemployers.org/-/media/Employers/Publications/Reward/Death-in-pensionablemembership-April-2020.pdf.

Published by the BMJ Publishing Group Limited. For permission to use (where not already granted under a licence) please go to http://group.bmj.com/group/rights-licensing/ permissions 